\title{
Diskresi Penyidik Polri Sebagai Alternatif Penanganan Perkara Pidana
}

\author{
Alfano Ramadhan \\ Magister Hukum Fakultas Hukum Universitas Islam Indonesia Yogyakarta Indonesia \\ Jln. Cik Di Tiro No. 1 Yogyakarta Indonesia \\ alfano.wb2012@gmail.com
}

\begin{abstract}
The purpose of this study is to identify, first, the application of investigator discretion at the Sleman Police in handling criminal acts as an effort to realize restorative justice. Second, the procedures for police investigators in exercising discretion as an effort to realize restorative justice. Third, the legal consequences of the discretion exercised by Polri investigators in the process of handling criminal cases. This study uses normative legal research with statutory and conceptual approaches. The results of this study conclude that first, the factors that encourage the investigative team to use their discretionary authority within the Sleman Police are the substance of the legislation; instructions from the Leader; investigators as law enforcers; as well as the situation and conditions in the investigation process. The external factor is the support from the community. Second, the application of discretion through a restorative justice approach changes the pattern of settlement to the needs of victims and improving public order compared to criminalizing someone. Third, the legal consequences that arise are that the rule of law is no longer the main choice in resolving cases in law enforcement efforts, this is due to the rule of law that does not fully accommodate the efforts to settle cases.
\end{abstract}

Key Words: Discretion; police examiners; restorative justice

\begin{abstract}
Abstrak
Tujuan dari penelitian ini adalah untuk mengetahui, pertama, penerapan diskresi penyidik di Polres Sleman dalam penanganan tindak pidana sebagai upaya mewujudkan restorative justice. Kedua, prosedur penyidik Polri dalam melakukan diskresi sebagai upaya mewujudkan restorative justice. Ketiga, akibat hukum atas diskresi yang dilakukan oleh penyidik Polri terhadap proses penanganan perkara pidana. Penelitian ini menggunakan penelitian hukum normatif dengan pendekatan perundang-undangan dan konseptual. Hasil dari penelitian ini menyimpulkan bahwa pertama, faktor yang mendorong tim penyidik dalam menggunakan wewenang diskresinya di lingkungan Polres Sleman adalah substansi perauran perundang-undangan; instruksi dari pimpinan; penyidik selaku penegak hukum; serta situasi dan kondisi dalam proses penyidikan. Faktor eksternal yaitu adanya dukungan dari masyarakat. Kedua, penerapan diskresi melalui pendekatan restorative justice merubah pola penyelesaiannya pada kebutuhan korban dan perbaikan ketertiban masyarakat dibandingkan dengan memidanakan seseorang. Ketiga, akibat hukum yang timbul adalah aturan hukum bukan lagi menjadi pilihan utama dalam penyelesaian perkara dalam upaya penegakan hukum, hal tersebut dikarenakan aturan hukum yang tidak sepenuhnya mengakomodir dalam upaya penyelesaian perkara.
\end{abstract}

Kata-kata Kunci: Diskresi; restorative justice; penyidik polisi 


\section{Pendahuluan}

Kepolisian Negara Republik Indonesia sebagai intitusi penegakkan hukum juga memiliki fungsi sebagai pelayan, pengayom, dan serta pelindung bagi masyarakat dari ancaman dan tindak kejahatan yang mengganggu serta mengancam rasa aman dan juga merugikan secara psikis maupun material, dengan cara memelihara keteraturan dan ketertiban sosial, menegakkan hukum atau lebih tepatnya menegakkan keadilan dalam masyarakat berdasarkan hukum. ${ }^{1}$ Salah satu dasar hukum yang dipakai dalam penegakkan hukum adalah hukum pidana. Hukum pidana dalam pengertiannya telah disepakati sebagai bagian dari hukum publik (algemene belangen). Dengan adanya sifat tersebut, apabila seseorang telah melakukan suatu tindak pidana yang merugikan kepentingan orang lain, maka akibat hukum terhadap pelaku tidak hanya menjadi hak dari korban tindak pidana tersebut, tetapi juga berkembang menjadi kewajiban bersama seluruh keluarga, masyarakat dan pada akhirnya akibat hukum tersebut menjadi bagian dari tanggung jawab negara. Aturan hukum dalam suatu Negara telah menjadi satu-satunya instrument dalam penyelesaian perkara pidana dengan prosedur serta aturan yang telah ditentukan. ${ }^{2}$

Konsep tersebut telah berlaku di Indonesia semenjak diundangkannya Undang-Undang Nomor 8 Tahun 1981 tentang Kitab Undang-Undang Hukum Acara Pidana (KUHAP). Dengan adanya peraturan perundang-undangan tersebut, penegakan hukum hanya bertumpu pada Negara sebagai pemberi keadilan yang ternyata berakibat pada sedikitnya keterlibatan peran individu dalam mengupayakan penyelesaian perkara tindak pidana. Pencarian keadilan dalam perkara tindak pidana sepenuhnya bertumpu pada sistem atau pola yang dibangun oleh Kepolisian, Kejaksaan, Pengadilan serta Lembaga Pemasyarakatan. Padahal keadilan yang sesungguhnya diberikan oleh Negara belum tentu sesuai dengan kehendak para pencari keadilan itu sendiri, sebab pada dasarnya setiap orang memiliki kebutuhan dan tingkat akseptabilitas yang beragam atas rasa keadilan. ${ }^{3}$

Secara lebih lanjut, Yahya Harahap mendeskripsikan terkait kritik terhadap lembaga pengadilan yaitu tenggat waktu penyelesaian sengketa melalui jalur litigasi memakan waktu yang sangat lama, estimasi dari biaya berperkara yang mahal, pengadilan yang kurang responsif, putusan pengadilan yang tidak

1 Markas Besar Kepolisian Negara Repulik Indonesia Sekolah Staf dan Pimpinan, Polmas Sebagai Implementasi Comunity Policing Bagaimana Menerapkannya?, hlm 3-4.

${ }^{2}$ Eva Achjani Zufa, Pergeseran Paradigma Pemidanaan, Lubuk Agung, Bandung, 2011, hlm. 2.

${ }^{3}$ Ibid., hlm. 3 
menyelesaikan masalah, dan kemampuan para hakim yang bersifat generalis. ${ }^{4}$ Kelemahan serta ketidakpuasan terhadap operasionalitas sistem peradilan pidana tersebut telah mendorong lembaga penegak hukum khususnya kepolisian untuk mencari solusi penyelesaian perkara alternatif dari sistem peradilan pidana yang ada dengan penyelesaian perkara di luar jalur penal, cara yang dimaksud yaitu dengan cara mediasi sebagai perwujudan dari restorative justice, sehingga diperlukan adanya pemikiran penyelesaian perkara pidana melalui jalur Alternative Dispute Resolution (ADR) dengan maksud agar dapat menyelesaikan konflik yang terjadi antara pelaku dengan korban yang juga untuk mengatasi pola formalitas dalam sistem peradilan pidana yang berlaku, serta menghindari efek negatif yang timbul dari sistem pemidanaan yang ada saat ini. ${ }^{5}$ Salah satu konsep untuk mewujudkan gagasan tersebut ialah dengan menerapkan pola restorative justice sebagai upaya dari penyelesaian perkara tindak pidana diluar pengadilan. Dilihat dari permasalahan-permasalahan tersebut di atas, mediasi terhadap para pihak dirasa lebih tepat dalam upaya mewujudkan asas peradilan sederhana, cepat dan murah yang amat penting untuk perlindungan hak dari korban maupun pelaku. ${ }^{6}$

Mekanisme terhadap mediasi yang merupakan bagian dari alternative dispute resolution (ADR), selama ini hanya dikenal dalam ranah hukum privat. Namun pada saat ini proses mediasi dalam upaya penegakan hukum mulai banyak dipraktikkan dalam penyelesaian perkara tindak pidana dikarenakan adanya suatu pergeseran tentang paradigma dalam penegakan hukum pidana dari pola keadilan retributif menjadi pola keadilan restoratif. Pada prinsip keadilan retributif, orientasi penyelesaian sengketa pidana ialah dengan pembalasan atas suatu tindak pidana terhadap pelaku dengan penjatuhan hukuman penjara sebagai bentuk dari putusan pengadilan. Sedangkan pada prinsip keadilan restoratif, terdapat suatu perkembangan terhadap penyelesaian sengketa yang dirasa lebih dapat memulihkan hak-hak terhadap korban dan mengakomodir kepentingan para pihak dengan memberikan keadilan dan kemanfaatan. Untuk mengakomodir kepentingan dari para pihak tersebut, maka upaya penyelesaian suatu perkara tindak pidana melalui mediasi dijadikan sebagai salah satu bentuk upaya penyelesaian sengketa diluar lembaga peradilan (non litigasi) dengan bantuan orang lain atau yang biasa disebut sebagai pihak ketiga yang bersifat netral serta tidak memihak dan tidak berperan sebagai pengambil keputusan

${ }^{4}$ M. Yahya Harahap, Beberapa Tinjauan mengenai Sistem Peradilan dan Penyelesaian Sengketa, Citra Aditya Bakti, Bandung, 1997, hlm. 153.

${ }_{5}^{5}$ Barda Nawawi Arief, Kebijakan Legislatif dalam Penanggulangan Kejahatan dengan Pidana Penjara, BP UNDIP cetakan ke-3, Semarang, 2000, hlm. 169-171.

${ }^{6}$ Ibid 
yang kemudian disebut sebagai mediator. Dalam hal ini tujuannya ialah untuk mencapai kesepakatan penyelesaian sengketa yang sedang dihadapi oleh para pihak tanpa ada yang merasa dikalahkan. ${ }^{7}$ Keuntungan penyelesaian suatu sengketa melalui upaya mediasi diantaranya yaitu biaya murah, estimasi waktu yang cepat, dapat memuaskan para pihak yang bersengketa karena melakukan upaya yang kooperatif, mengurangi penumpukan perkara, menghilangkan unsur dendam, mempererat hubungan silaturahmi dan dapat memperkuat serta memaksimalkan fungsi dari lembaga peradilan dalam upaya penyelesaian sengketa disamping proses pengadilan yang bersifat memutus (ajudikatif).

Melalui pola penyelesaian perkara tindak pidana dengan upaya diskresi, para penyidik Polri memiliki kewenangan untuk mengambil keputusan atau memberi kebijakan lain di luar aturan perundang-undangan dalam menyelesaikan perkara pidana yang ditangani dengan didasarkan pada situasi serta kondisi, yang bertujuan untuk kepentingan secara umum. Sedangkan restorative justice secara sederhana dapat dimaknai sebagai suatu upaya untuk menyelesaikan perkara tindak pidana yang melibatkan masyarakat, korban, dan pelaku kejahatan dengan tujuan agar tercipta keadilan bagi seluruh pihak dengan harapan terciptanya suatu keadaan yang sama seperti sebelum terjadinya tindak pidana dan mencegah terjadinya kejahatan lebih lanjut. Sebagai suatu filosofi pemidanaan yang bermartabat, maka didalam implementasinya dibutuhkan suatu konsep yang dapat memiliki suatu legitimasi yang konkrit.

\section{Rumusan Masalah}

Berdasarkan latar belakang di atas, maka rumusan masalah dalam penelitian ini yaitu, pertama, bagaimanakah penerapan diskresi penyidik Polri dalam penanganan tindak pidana sebagai upaya mewujudkan restorative justice? Kedua, bagaimanakah prosedur penyidik Polri dalam melakukan diskresi sebagai upaya mewujudkan restorative justice? Ketiga, apakah akibat hukum atas diskresi yang dilakukan oleh penyidik Polri terhadap proses penanganan perkara pidana?

\section{Tujuan Penelitian}

Berdasarkan rumusan masalah sebagaiaman diuraikan di atas, maka tujuan penelitian ini, untuk mengetahui: pertama, penerapan diskresi oleh penyidik Polri dalam penanganan tindak pidana sebagai upaya mewujudkan restorative justice; kedua, prosedur penyidik Polri dalam melakukan diskresi sebagai upaya mewujudkan restorative justice; dan ketiga, akibat hukum atas

${ }^{7}$ M. Yahya Harahap, Op. Cit., hlm. 59 
diskresi yang dilakukan oleh penyidik Polri terhadap proses penanganan perkara pidana.

\section{Metode Penelitian}

Penelitian yang digunakan adalah penelitian normatif, yaitu menganalisis suatu permasalahan hukum berdasarkan peraturan perundang-undangan yang berlaku. ${ }^{8}$ Penelitian hukum normatif menitikberatkan pada penelitian kepustakaan guna mendapatkan data sekunder sebagai data utamanya. ${ }^{9}$ Pendekatan-pendekatan yang digunakan di dalam penelitian hukum adalah pendekatan undang-undang (statute approach) dan pendekatan konseptual (conceptual approach). ${ }^{10}$ Penelitian ini menggunakan bahan hukum primer dan sekunder. Adapun pengumpulan data dalam penelitian ini dilakukan dengan cara studi pustaka, yaitu mempelajari, menelaah dan menganalisis data sekunder sebagai data utama dalam penelitian ini. Di samping itu juga dilakukan wawancara dengan nara sumber guna melengkapi data dalam penelitian ini. Untuk menganalisis data yang diperoleh, akan digunakan metode deskriptif kualitatif. ${ }^{11}$ Disebabkan karena penelitian hukum ini bersifat normatif maka diperlukan sebagai premis mayor berupa aturan hukum kemudian pengajuan premis minor yaitu fakta hukum, dari kedua hal tersebut kemudian

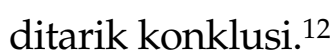

\section{Hasil Penelitian dan Pembahasan}

\section{Penerapan Diskresi Penyidik Polri dalam Penanganan Tindak Pidana Sebagai Upaya Mewujudkan Restorative Justice}

Dasar hukum penerapan diskresi dapat diuraikan sebagai berikut. Sistem peradilan pidana yang dianut oleh KUHAP dan aturan hukum acara pidana yang bersifat khusus, merupakan sistem pidana terpadu (integrated criminal justice system) yang diletakkan di atas prinsip diferensiasi fungsional yakni membedakan antara fungsi dan wewenang dari setiap komponen penegak hukum berdasarkan instansi nya. Sistem peradilan pidana terpadu tersebut, menempatkan segenap aparat penegak hukum pada posisi yang sejajar berdasarkan fungsi dan kewenangan nya. ${ }^{13}$

\footnotetext{
${ }^{8}$ Mukti Fajar ND dan Yulianto Achmad, Dualisme Penelitian Hukum Normatif dan Empiris, Pustaka Pelajar, Yogyakarta, 2010, hlm. 44

${ }_{9}^{9}$ M. Syamsudin, Operasionalisasi Penelitian Hukum, JPT RajaGrafindo Persada, Jakarta, 2007, hlm. 25

${ }_{10}$ Peter Mahmud Marzuki, Penelitian Hukum, Prenada Media Grup, Jakarta, 2011, hlm. 93

11 M. Syamsudin, Operasionalisasi Penelitian Hukum, PT RajaGrafindo Persada, Jakarta, 2007, hlm. 126

12 Philipus M. Hadjon, Makalah Pelatihan Argumentasi Hukum Fakultas Hukum Universitas Airlangga, Dasar Argumentasi Hukum dan Legal Opinion (Legal Memo), 18 Juni 2004

13Ruslan Renggong, Hukum Acara Pidana (Memahami Perlindungan HAM dalam Proses Penahanan di Indonesia), Kencana, Jakarta, 2014, hlm. 164
} 
Polisi adalah aparat penegak hukum jalanan yang langsung berhadapan dengan masyarakat. Peran Polisi secara umum dikenal sebagai pemeliharaan keamanan dan ketertiban masyarakat yang juga sebagai aparat penegak hukum dalam proses pemiidanaan. Dalam melaksanakan tugasnya sehari-hari, polisi selalu bercengkrama dan kontak langsung dengan masyarakat sebagai obyek dari tugas pemolisian, artinya dimana ada masyarakat disitu ada polisi yang bertugas untuk menjaga ketertiban dan keamanan dimasyarakat dari segala bentuk kejahatan mulai dari antisipasi atau pencegahan sampai kepada penindakan terhadap suatu kejahatan. ${ }^{14}$

Fungsi Kepolisian menurut Pasal 2 Undang-Undang No. 2 Tahun 2002 adalah "salah satu fungsi pemerintah negara di bidang pemeliharaan keamanan dan ketertiban masyarakat, penegakan hukum, perlindungan, pengayoman, dan pelayanan kepada masyarakat." Oleh karena itu di dalam rangka penegakan hukum (Law Enforcement), Kepolisian mempunyai tugas penyidikan terhadap suatu perkara pidana yang merupakan implementasi dari fungsi Kepolisian tersebut dan amanat dari Pasal 6 ayat (1) UU No. 8 Tahun 1981 tentang Kitab Undang-Undang Hukum Acara Pidana. Namun pelaksanaan penyidikan dalam mengungkap suatu perkara pidana pada sub sistem penyidikan oleh Kepolisian tidak selalu mudah untuk dilakukan. ${ }^{15}$

Lembaga Kepolisian dalam hal ini secara penuh memiliki peran sebagai ujung tombak dalam upaya penegakan hukum khususnya pada tindak pidana yang mempunyai tugas dan kewenangan atas suatu perbuatan tersebut perlu dihentikan proses penyelesaian perkaranya atau perlu adanya tindak lanjut dalam proses peradilan tindak pidana dengan alasan-alasan tertentu. Aturan perundang-undangan yang menjadi latar belakang atas upaya tersebut ialah Pasal 18 ayat (1) Undang-Undang Nomor 2 Tahun 2002 tentang Kepolisian Negara Republik Indonesia, yang berbunyi; “Untuk kepentingan umum dan masyarakat, pejabat Kepolisian Negara Republik Indonesia dalam melaksanakan fungsi, tugas, dan wewenangnya dapat bertindak menurut penilaiannya sendiri". Sedangkan pada ayat (2) dalam UU tersebut dijelaskan bahwa pelaksanaan ketentuan sebagaimana dimaksud dalam ayat (1) hanya dapat dilakukan dalam keadaan yang sangat perlu dengan memperhatikan peraturan perundang-undangan, serta Kode Etik Profesi Kepolisian Negara Republik Indonesia. Oleh karena itu, dalam menjalankan tugas dan wewenangnya para penyidik dari kepolisian memiliki kewenangan melakukan upaya diskresi untuk menentukan tindakan yang selanjutnya akan dilakukan. Secara sederhana, dalam memahami konsep diskresi

${ }^{14}$ Ibid., hlm. 175

15 Ibid., hlm. 176 
pada kepolisian ialah memahami bahwa kepolisian memiliki kewenangan untuk mengambil keputusan dan/atau memilih berbagai tindakan dalam menyelesaikan perkara tindak pidana yang ditanganinya dengan berdasarkan pada hukum atas dasar situasi dan kondisi, serta menurut pertimbangan dan keputusan hati nurani secara pribadi demi kepentingan umum. ${ }^{16}$ Diskresi kepolisian secara tidak langsung dapat dipergunakan dalam penerapan terhadap proses mediasi dalam penanganan perkara antara kedua belah pihak yaitu pelaku dan korban dari suatu perbuatan tindak pidana untuk menyelesaikan permasalahan hukum yang baik serta untuk mencapai keadilan dan kemanfaatan yang merupakan bagian dari tujuan hukum. Sehingga dalam hal ini polisi dapat menjadi pahlawan bagi bangsanya, dengan membuat pilihan tepat dalam menjalankan tugas dan kewenangannya sebagai profesi polisi. ${ }^{17}$

Kewenangan diskresi yang dimiliki Polisi selaku institusi negara selaku pejabat publik dalam hal penegakan hukum (Law Enforcement) sudah tak asing lagi, akan tetapi pada saat seorang penyidik menangani suatu proses perkara pidana, terkadang seorang Penyidik Kepolisian dihadapkan kepada suatu masalah-masalah yang dirasa ringan, kurang efektif dan efisien untuk dilakukannya penyidikan sampai dilimpahkan (P21) ke Penuntut Umum Kejaksaan, dan selanjutnya ke tahap Pengadilan untuk diputus oleh Hakim. Mengingat hal tersebut, maka manfaat diskresi dari Kepolisian ini adalah menjadikan pelaksanaan kebijakan yang didasari oleh profesionalisme dalam bekerja dari Kepolisian yang dituntut untuk bekerja secara maksimal dalam memberikan suatu pelayan, pembinaan serta pengayoman kepada masyarakat luas secara umumnya dan menegakkan hukum secara khususnya dari Polisi lebih efektif dan efisien. ${ }^{18}$

Menurut Kapolsek Depok Timur, Sleman, Yogyakarta, Kompol. Drs. Paridal pengertian diskresi adalah "tindakan penyidik menurut penilaiannya sendiri untuk menentukan suatu perkara lanjut ke Pengadilan atau diselesaikan secara kekeluargaan atau dapat juga diartikan suatu kebijaksanaan berdasarkan keluasannya untuk melakukan suatu tindakan atas dasar pertimbangan dan keyakinan dirinya. Jadi diskresi itu dilakukan bukan lepas dari ketentuan hukum tetapi diskresi itu tetap dilakukan dalam kerangka hukum. ${ }^{19}$

\footnotetext{
${ }^{16}$ Sitompul, Beberapa Tugas dan Peran Polri, CV. Wanthy Jaya, Jakarta, 2000, hlm. 2.

${ }_{17}$ Satjipto Raharjo, Membangun Polisi sipil, Perspektif Hukum, Sosial, dan Kemasyarakatan, PT Kompas Media Nusantara, Jakarta, 2007, hlm. 262 $15-16$.

${ }^{18}$ M. Faal, Penyaringan Perkara Pidana Oleh Polisi (Diskresi Kepolisian), Pradanya Paramita, Jakarta, 1991, hlm.

${ }^{19}$ Hasil wawancara dengan Kompol Paridal pada 29 November 2019, di Polsek Depok Timur, Sleman, D.I.Y.
} 
Menurut M Faal "diskresi polisi merupakan suatu kebijaksanaan berdasarkan kekuasaan untuk melakukan suatu tindakan atas dasar pertimbangan dan keyakinan dirinya." Selanjutnya menurut Faal "apabila kata diskresi itu digabungkan dengan kata Kepolisian, maka istilah menjadi diskresi penyidik". Yang dapat diartikan suatu kebijaksanaan berdasarkan kekuasaan (power) untuk melakukan suatu tindakan atas dasar pertimbangan dan keyakinan dirinya. Jadi, diskresi dikaitkan dengan Kepolisian dan penyidik adalah suatu kebijaksanaan penyidik berdasarkan kekuasaan (power) untuk melakukan suatu tindakan atas dasar pertimbangan dan penilaiannya sendiri. ${ }^{20}$

Konsep mengenai diskresi terdapat dalam Undang-Undang Negara Republik Indonesia No. 2 Tahun 2002 tentang Kepolisian Negara Republik Indonesia terdapat pada Pasal 18 ayat (1) dan ayat (2) yang berbunyi:

“Untuk kepentingan umum, pejabat Kepolisian Negara Republik Indonesia dalam melaksanakan tugas dan wewenangnya dapat bertindak menurut penilaiannya sendiri."

Selanjutnya ayat (2) berbunyi;

"Pelaksanaan ketentuan sebagaimana dimaksud pada ayat (1) hanya dapat dilakukan dalam keadaan yang sangat perlu dengan memperhatikan peraturan perundang-undangan, serta kode etik profesi Kepolisian."21

Pada Bab Penjelasan resmi dari Undang-Undang Nomor 2 Tahun 2002 tersebut berbunyi ayat (1) telah dijelaskan lebih lanjut bahwa yang dimaksud "bertindak menurut penilaiannya sendiri" adalah suatu tindakan yang dapat dilakukan oleh anggota Kepolisian Negara Republik Indonesia yang dalam bertindak harus mempertimbangkan manfaat serta resiko dari tindakannya dan betul-betul untuk kepentingan umum. Dari penjelasan tersebut mempunyai makna dalam pelaksanaan diskresi tersebut harus didasari aspek kepentingan umum. Meskipun tindakan tersebut dilakukan menurut penilaiannya sendiri harus mempertimbangkan manfaat serta resiko yang timbul setelah tindakan tersebut sesuai dengan kewenangan dan jabatan seorang aparat Kepolisian. ${ }^{22}$

Penerapan diskresi oleh polisi juga harus berdasar diskresi dibutuhkan dan dilakukan oleh Polisi karena ia bukan hanya aparat penegak hukum tetapi juga penjaga ketertiban yang bertugas mengusahakan kedamaian (peacekeeping) dan ketertiban (order maintance). Peran polisi dalam penegakan hukum seolah - olah diibaratkan bahwa Polisi adalah hukum yang hidup, karena ditangan Polisi inilah

${ }^{20}$ M. Faal, Op. Cit., hlm. 20

${ }^{21}$ Undang-Undang Negara Republik Indonesia No. 2 Tahun 2002 tentang Kepolisian Negara Republik Indonesia terdapat pada Pasal 18 ayat (1) dan (2).

22 Warsito Hadi Utomo, Hukum Kepolisian Di Indonesia. Prestasi Pustaka, Jakarta, 2005, hlm. 106 
tujuan-tujuan hukum untuk melindungi dan menciptakan keadaan yang aman di dalam masyarakat dapat diwujudkan. Melalui tangan Polisi inilah hal-hal yang bersifat falsafati dalam hukum dapat diwujudkan menjadi nyata, tetapi justru karena sifat pekerjaannya yang demikian itulah, Polisi banyak berhubungan dengan masyarakat dan menanggung resiko mendapatkan sorotan yang tajam pula dari masyarakat yang dilayaninya. ${ }^{23}$

Fungsi polisi secara umum adalah untuk menjalankan kontrol sosial masyarakat yang bersifat preventif dan represif, dalam bahasa Perancis dikenal dengan istilah la police administration. ${ }^{24}$ Fungsi tersebut diatur dalam UU No. 2 Tahun 2002 tentang Kepolisian Negara Republik Indonesia dan KUHAP. Dalam Pasal 2 UU Nomor 2 Tahun 2002 tentang Kepolisian Republik Indonesia, "Fungsi Kepolisian adalah salah satu fungsi pemerintahan negara di bidang pemeliharaan keamanan dan ketertiban masyarakat, penegakan hukum, perlindungan, pengayoman, dan pelayanan kepada masyarakat". ${ }^{25}$

Dalam Pasal 4 UU No. 2 Tahun 2002 juga menegaskan "Kepolisian Negara RI bertujuan untuk mewujudkan keamanan dalam negeri yang meliputi terpeliharanya keamanan dan ketertiban masyarakat, tertib, dan tegaknya hukum, terselenggaranya perlindungan, pengayoman, dan pelayanan kepada masyarakat, serta terbinanya ketentraman masyarakat dengan menjunjung tinggi hak asasi manusia". Dalam melaksanakan tugas pokok tersebut, Pasal 14 ayat (1) Huruf g UU No. 2 Tahun 2012 tentang Kepolisian Negara Republik Indonesia dinyatakan bahwa Kepolisian Negara Republik Indonesia bertugas untuk melakukan penyelidikan dan penyidikan terhadap semua tindak pidana sesuai dengan hukum acara pidana dan peraturan perundang-undangan lainnya. Dalam Pasal 16 ayat (1) Undang-Undang Nomor 2 Tahun 2002 tentang Kepolisain Negara Republik Indonesia, dinyatakan bahwa dalam rangka menyelenggarakan tugas sebagaimana dimaksud dalam Pasal 13 dan 14 di bidang proses pidana, Kepolisian Negara Republik Indonesia berwenang untuk melakukan beberapa tindakan yang sangat urgen. ${ }^{26}$

Dalam Pasal 16 ayat (2) Undang-Undang Nomor 2 Tahun 2002 Tentang Kepolisian Negara Republik Indonesia, dinyatakan bahwa tindakan lain sebagaimana yang dimaksud dalam Pasal 16 ayat (1) huruf I adalah sebagai tindakan penyelidik dan penyidikan yang dilaksanakan jika memenuhi syarat

${ }^{23}$ Chrysnanda Dwilaksana, Corak Diskresi dalam Proses Penyidikan Kecelakaan Lalu Lintas, UI, Jakarta, 2001, hlm. 36, dikutip dalam Riswanto, hlm. 86.

${ }^{24}$ Satjipto Rahardjo, Polisi Sipil Dalam Perubahan Sosial Di Indonesia, Kompas, Jakarta, 2009, hlm. 28

${ }^{25}$ Op. Cit., Made, hlm. 43

${ }^{26}$ Koerniatmanto Soetoprawiro, dkk, Sistem Pertanggungjawaban Hukum Kepolisian Negara Republik Indonesia Secara Organisasional Maupun Personal, Naskab Publikasi, Lembaga Penelitian dan Pengabdian kepada Masyarakat,Universitas Katolik Prahayangan, Bandung, 2013, hlm. 22. 
sebagai berikut; Tidak bertentangan dengan suatu aturan hukum; Selaras dengan kewajiban hukum yang mengharuskan tindakan tersebut dilakukan; Harus patut, masuk akal, dan termasuk dalam lingkungan jabatannya; Pertimbangan yang layak berdasarkan keadaan yang memaksa; dan Menghormati hak asasi manusia.

Dalam Pasal 18 ayat (1), Untuk kepentingan umum, pejabat Kepolisian Negara Republik Indonesia dapat bertindak menurut penilaiannya sendiri. Ayat (2) Pelaksanaan ketentuan sebagaimana dimaksud dalam ayat (1) hanya dapat dilakukan dalam keadaan yang sangat perlu dengan memperhatikan peraturan perundang-undangan, serta kode etik profesi Kepolisian Negara Republik Indonesia. Pasal tersebut menjelaskan bahwa anggota Polri dalam melaksanakan tugas memiliki apa yang disebut dengan diskresi. Sehingga dengan dimilikinya kewenangan diskresi dibidang yudisial yang tertuang dalam UU No. 2 Tahun 2002 pada Pasal 18 ayat (1) bahwa "Untuk kepentingan umum pejabat Kepolisian Negara Republik Indonesia dalam melaksanakan tugas dan wewenangnya dapat bertindak menurut penilaiannya sendiri". Tentunya dalam melakukan tindakan tersebut harus sesuai dengan Pasal 4 UU No. 2 Tahun 2002 yaitu dengan menjunjung tinggi hak asasi manusia.

Pada Pasal 22 ayat (2) huruf b dan c Undang-Undang No. 30 Tahun 2014 tentang Administrasi Pemerintahan dinyatakan bahwa setiap penggunaan diskresi pejabat pemerintahan bertujuan untuk mengisi kekosongan hukum dan memberikan kepastian hukum. ${ }^{27}$

Pelaksanaan konsep restorative justice dalam kasus penggelapan di Polres Sleman adalah bagian dari diskresi kepolisan. Bahwa kasus penggelapan merupakan suatu bentuk kasus yang termasuk dalam delik aduan. Delik aduan terjadi apabila ada pengaduan atau laporan dari orang yang menjadi korban tindak pidana. Misalnya pemerkosaan, pencurian dalam keluarga dan pencurian dalam waktu pisah meja-ranjang. Delik aduan bisa ditarik kembali apabila si pelapor menarik laporannya misalnya karena ada perdamaian atau perjanjian damai yang diketahui oleh penyidik bila telah masuk tingkat penyidikan, oleh jaksa bila telah masuk tingkat penuntutan atau oleh hakim bila masuk persidangan tetapi belum divonis. Penarikan aduan atau laporan biasanya terjadi dalam kasus perkosaan di mana si korban merasa malu atau si pelaku mau menikahi korban. Dalam kasus pencurian dalam keluarga atau pisah mejaranjang, biasanya alasan keluarga. Kepolisian dalam pelaksanaan tugasnya mengenal istilah diskresi yaitu suatu kekuasaan atau wewenang yang dilakukan berdasarkan hukum atas pertimbangan dan keyakinan serta lebih menekankan pertimbangan-pertimbangan moral dari pada pertimbangan hukum. Diskresi

${ }^{27}$ Lihat Surat Edaran Kapolri Nomor : SE/8/VII/2018, 27 Juli 2018. 
menyangkut pengambilan keputusan yang tidak terikat oleh hukum, dimana penilaian pribadi juga memegang peranan. Diskresi Kepolisian adalah suatu wewenang menyangkut pengambilan suatu keputusan pada kondisi tertentu atas dasar pertimbangan dan keyakinan pribadi seorang anggota kepolisian ${ }^{28}$

\section{Faktor Diperlukannya Penerapan Diskresi dalam Bentuk Mediasi Penal pada Penyelesaian Perkara Tindak Pidana di Polres Sleman}

Mediasi merupakan salah satu bentuk dari alternatif penyelesaian sengketa di luar pengadilan. Tujuan dilakukannya mediasi adalah menyelesaikan sengketa antara para pihak dengan melibatkan pihak ketiga yang netral dan imparsial. Mediasi dapat mengantarkan para pihak ketiga pada perwujudan kesepakatan damai yang permanen dan lestari, mengingat penyelesaian sengketa melalui mediasi menempatkan kedua belah pihak pada posisi yang sama, tidak ada pihak yang dimenangkan atau pihak yang dikalahkan (win-win solution)..$^{29}$

Dalam mediasi para pihak yang bersengketa proaktif dan memiliki kewenangan penuh dalam pengambilan keputusan. Mediator tidak memiliki kewenangan dalam pengambilan keputusan, tetapi ia hanya membantu para pihak dalam menjaga proses mediasi guna mewujudkan kesepakatan damai mereka. ${ }^{30}$ Penyelesaian sengketa melalui jalur mediasi sangat dirasakan manfaatnya, karena para pihak telah mencapai kesepakatan yang mengakhiri persengketaan mereka secara adil dan saling menguntungkan. Bahkan dalam mediasi yang gagal pun, di mana para pihak belum mencapai kesepakatan, sebenarnya juga telah merasakan manfaatnya. ${ }^{31}$ Model utama penyelesaian sengketa adalah keinginan dan iktikad baik para pihak dalam mengakhiri persengketaan mereka. Keinginan dan iktikad baik ini, kadang-kadang memerlukan bantuan pihak ketiga dalam perwujudannya. Mediasi merupakan salah satu bentuk penyelesaian sengketa yang melibatkan pihak ketiga.

Dalam rangka menjawab perkembangan kebutuhan hukum masyarakat serta memenuhi rasa keadilan semua pihak, Kepolisian Negara Republik Indonesia selaku intitusi yang diberikan kewenangan selaku penyidik tindak pidana, merasa perlu untuk merumuskan konsep baru dalam sistem penegakan hukum pidana, merasa perlu untuk merumuskan konsep baru dalam sistem penegakan hukum pidana terutama proses penyelidikan dan penyidikan tindak

28 Ibid., Anggaito

${ }^{29}$ Bowo, Kepala unit 4 Reskrim Polres Sleman, Faktor diperlukannya mediasi penal dalam penyelesaian perkara pidana penggelapan, wawancara, 24 Desember 2018.

${ }^{30}$ Ibid., Bowo

31 http://handarsubhandi.blogspot.com/2014/11/tujuan-dan-manfaat-mediasi.html Handar Subandi, Diakses pada 25 Desember 2018. 
pidana yang mampu mengakomodir nilai-nilai keadilan dalam masyarakat sekaligus memberikan kepastian hukum terutama kepastian proses. ${ }^{32}$

Proses penyelesaian perkara pidana dapat dilakukan dengan cara yang sesuai dengan KUHAP dan dapat juga dengan menggunakan proses penyelesaian perkara di luar pengadilan. Pada penerapan mediasi penal pada perkara tindak pidana di Polres Sleman berikut dapat dilihat pada tabel yang ditampilkan. Menurut data hasil Rekapitulasi data penerapan Diskresi dalam Penyelesaian Perkara di Polres Sleman, D.I.Y, sebagai berikut: ${ }^{33}$

Rekapitulasi Penerapan Diksresi Dalam Penyelesaian Perkara Satreskrim Polres Sleman Tahun 2019

\begin{tabular}{cccccccc}
\hline \multirow{2}{*}{ No } & \multirow{2}{*}{ Bulan } & \multicolumn{5}{c}{ Unit } & \multirow{2}{*}{ Total } \\
\cline { 3 - 6 } & & I & II & III & IV & PPA & \\
\hline 1 & JANUARI & 6 & 5 & 8 & 5 & 6 & 30 \\
2 & FEBRUARI & 7 & 7 & 10 & 10 & 9 & 43 \\
3 & MARET & 12 & 11 & 5 & 6 & 6 & 40 \\
4 & APRIL & 2 & 1 & 1 & 6 & 5 & 15 \\
5 & MEI & 3 & 4 & 2 & 3 & 7 & 19 \\
6 & JUNI & 4 & 4 & 3 & 4 & 3 & 18 \\
7 & JULI & 3 & 4 & 3 & 5 & 4 & 19 \\
8 & AGUSTUS & 6 & 7 & 2 & 3 & 3 & 21 \\
9 & SEPTEMBER & 5 & 7 & 3 & 4 & 3 & 22 \\
10 & OKTOBER & 6 & 5 & 8 & 7 & 5 & 31 \\
11 & NOVEMBER & 3 & 1 & 9 & 4 & 4 & 21 \\
12 & DESEMBER & 4 & 5 & 3 & 7 & 1 & 20 \\
\multicolumn{2}{c}{ TOTAL PER UNIT } & 61 & 61 & 57 & 64 & 56 & 299 \\
\hline
\end{tabular}

Sumber : Polres Sleman

\section{Prosedur Penyidik Polri dalam Melakukan Diskresi sebagai Upaya Mewujudkan Restorative Justice}

Berdasarkan landasan perundang-undangan mengenai tugas dan kewenangan kepolisian didalam membentuk diskresi seperti telah dijelaskan sebelumnya, maka diberitahukan/dipermaklumkan untuk penyelesaian perkara dengan pendekatan Restorative Justice agar tidak memunculkan keberagaman administrasi penyelidikan/penyidikan dan perbedaan intepretasi para penyidik serta penyimpangan dalam pelaksanaannya diperlukan pedoman penanganan sebagaimana telah diatur sebagai berikut :34

\footnotetext{
${ }^{32}$ Ibid.

${ }^{33}$ Data Satreskrim Polres Sleman

${ }^{34}$ Lihat Surat Edaran Kapolri Nomor : SE/8/VII/2018, 27 Juli 2018.
} 
a. Terpenuhi syarat materil yaitu :

1) Tidak menimbulkan keresahan masyarakat dan tidak ada penolakan masyarakat.

2) Tidak berdampak konflik sosial

3) Adanya pernyataan dari semua pihak yang terlibat untuk tidak keberatan dan melepaskan hak menuntutnya dihadapan hukum.

4) Prinsip pembatas;

a) Pada pelaku;

i. Pelaku bukan residivis

ii. Tingkat kesalahan pelaku relatif tidak berat, yakni kesalahan (schuld atau mensrea dalam bentuk kesengajaan terutama kesengajaan sebagai maksud atau tujuan)

b) Pada tindak pidana dalam proses

i. Penyelidikan

ii. Penyidikan sebelum SPDP dikirim ke penuntut umum

b. Terpenuhi syarat formil yaitu :

1) Surat permohonan perdamaian kedua belah pihak (pelapor dan terlapor)

2) Surat pernyataan perdamaian (akte van dading) dan penyelesaian perselisihan para pihak yang berperkara (pelapor dan/atau keluarga pelapor, terlapor dan/atau keluarga terlapor dan perwakilan dari tokoh masyarakat) diketahui oleh atasan penyidik.

3) Berita acara pemeriksaan tambahan pihak yang berpekara setelah dilakukan penyelesaian perkara melalui keadilan restoratif.

4) Rekomendasi gelar perkara khusus yang menyetujui penyelesaian keadilan restoratif

5) Pelaku tidak keberatan atas tanggungjawab, ganti rugi, atau dilakukan dengan sukarela.

6) Semua tindak pidana dapat dilakukan restorative justice terhadap kejahatan umum yang tidak menimbulkan korban jiwa.

Langkah prosedural yang Penyidik ambil dalam menjalankan konsep mediasi penal untuk mewujudkan keadilan restoratif dalam perkara tindak pidana penggelapan sesuai dengan Surat Edaran Kapolri Nomor : SE/8/VII/2018, 27 Juli 2018 :

1) Setelah menerima permohonan perdamaian kedua belah pigak (pelapor dan terlapor) yang ditanda tangani diatas materai, dilakukan penelitian administrasi syarat formil penyelesaian perkara melalui keadilan restoratif.

2) Permohonan perdamaian setelah persyaratan formil terpenuhi diajukan kepada atasan penyidik untuk mendapatkan persetujuan.

3) Setelah permohonan disetujui oleh atasan penyidik (Kabareskrim, Kapolda/Kapolres), kemudian ditetapkan waktu pelaksanaan penandatanganan pernyataan perdamaian. 
4) Pelaksanaan konfersi yang menghasilkan perjanjian kesepakatan yang ditandatangani semua pihak yang terlibat.

5) Membuat nota dinas kepada pengawas peyidik atau kasatker perihal permohonan dilaksanakan gelar perkara khusus untuk tujuan penghentian perkara.

6) Melaksanakan gelar perkara khusus dengan peserta pelapor, terlapor dan/atau keluarga terlapor dan perwakilan dari tokoh masyarakat yang ditunjuk oleh penyidik, penyidik yang menangani dan perwakilan dari fungsi pengawas internal dan fungsi hukum dan unsur bila diperlukan.

7) Menyusun kelengkapan administrasi dan dokumen gelar perkara khusus serta laporan hasil gelar perkara.

8) Menerbitkan surat perintah penghentian penyelidikan/penyidikan dan surat ketetapan penghentian penyelidikan/penyidikan dengan alasan restorative Justice.

9) Untuk perkara pada tahan penyelidikan, penyelidik menerbitkan surat perintah penghentian penyelidikan dan surat ketetapan penyelidikan yang ditanda tangani oleh :

a) Direktur Reserse Kriminan pada tingkat Mabes Polri,

b) Direktur Reserse Kriminal pada tingkat Polda.

c) Kapolres pada tingkat Polres dan Polsek.

10) Untuk perkara pada tahap penyidikan, penyidik menerbitkan surat perintah penghentian penyidikan dan surat ketetapan penghentian penyidikan ditanda tangani oleh :

a) Direktur Reserse Kriminan pada tingkat Mabes Polri,

b) Direktur Reserse Kriminal pada tingkat Polda.

c) Kapolres pada tingkat Polres dan Polsek.

11) Mencatatkan ke dalam buku register baru B-19 sebagai perkara restoratif dihitung sebagai penyelesaian perkara.

\section{Akibat Hukum atas Diskresi yang dilakukan oleh Penyidik Polri terhadap Proses Penanganan Perkara Pidana}

Bahwa dengan diterapkannya Diskresi Kepolisian telah berakibat pada implikasi terhadap hukum, artinya dengan dilaksanakkannya Diskresi Kepolisian maka hukum yang ada akan berbenturan dengan realita kehidupan masyarakat. Dalam hal ini apabila hukum merupakan solusi pemecahan atas permasalahan yang paling tepat dari semua alternatif pemecahan yang ada, maka ketentuan hukum itulah yang akan diterapkan. Sebaliknya bila ketentuan hukum itu tidak akan menguntungkan, terlebih lebih lagi bila justru akan menimbulkan situasi dan kondisi yang lebih buruk dari sebelumnya, maka ketentuan hukum itu tidak akan diterapkan alias dikesampingkan. Sebagai contoh anggota satuan lalu lintas Polsek Depok Timur pernahemngatur lalu lintas tentang garis jalan yang tidak terputus putus namun terpaksa harus dilanggar oleh pengguna jalan karena adannya hambatan truk mogok didepannya. Ketentuan lalu lintas ini pada situasi 
dan kondisi yang demikian tidak dapat diterapkan, sebab bila diterapkan justru akan menimbulkan situasi dan kondisi lalu lintas yang semakin buruk yang selanjutnya akan berkembang menjadi terganggunya stabilitas keamanan dan kesejahteraan masyarakat. ${ }^{35}$

\section{Penutup}

Berdasarkan pembahasan sebelumnya, maka kesimpulan dalam penelitian ini yaitu. Pertama, Faktor yang mendorong penyidik dalam menggunakan wewenang diskresinya pada saat penyidikan terhadap suatu tindak pidana di lingkungan hukum Polres Sleman adalah; Faktor internal yang berupa; substansi peraturan perundang-undangan; instruksi dari pimpinan; penyidik sebagai penegak hukum; situasi dalam penyidikan, faktor eksternal yang mendorong diskresi penyidik ialah dukungan dari masyarakat. Kedua, penerapan diskresi melalui pendekatan Restorative justice menjadi hal penting sebagai wujud mekanisme informal dan non ajudikatif dalam menangani konflik atau permasalahan kejahatan dimana pelaku, korban dan masyarakat mengambil peranan penting dalam pengambilan keputusan. Pendekatan Restorative justice bertujuan untuk merubah pengarahan hukum pidana dengan merubah fokusnya pada kebutuhan korban dan perbaikan ketertiban masyarakat dibandingkan dengan mudahnya memidanakan seseorang. Ketiga, akibat hukum dari pelaksanaan dikresi kepolisian adalah aturan hukum bukan menjadi sebuah piihan utama dalam penegakan hukum. Hal ini dikarenakan karena tauran aturan hukum juga tidak sepenuhnya mengakomodir dan tidak selalu dapat memecahkan permasalahan masyarakat secara sempurna. Faktanya hukum memang memiliki keunggulan keunggulan komparatif, namun juga mempunyai kelemahan kelemahan secara mendasar yang tidak dapat diabaikan, serta dapat diandalkan untuk menyelesaikan permasalahan yang dihadapi masyarakat.

Saran yang diberikan sebagai berikut. Pertama, sekalipun kewenangan diskresi yang dimiliki Polisi begitu luas, namun dalam melaksanakan kewenangan tersebut Polisi tidak boleh sewenang-wenang, tetapi hendaknya tetap dalam batas-batas yang telah ditentukan oleh hukum. Dalam konteks studi kasus pada lingkungan Polres Sleman, Pimpinan angggota kepolisian pada wilayah hukum Sleman diharapkan selalu melakukan pengawasan melekat terhadap pelaksanaan tugas polisi di lapangan. Kedua, dalam penerapan diskresi, anggota kepolisian khususnya anggota kepolisian pada wilayah hukum Polres Sleman dan Polsek Depok Timur, Sleman dapat lebih menekankan penerapan

${ }^{35}$ Hasil Studi Kasus pada wilayah Polres Sleman pada 29 November 2019. 
restorative justice melalui kewenagan diskeresi seperti mediasi dengan melibatkan masyarakat yang terkait.

\section{Daftar Pustaka}

\section{Buku}

Achjani Zufa, Eva, Pergeseran Paradigma Pemidanaan, Lubuk Agung, Bandung, 2011.

Faal, M., Penyaringan Perkara Pidana Oleh Polisi (Diskresi Kepolisian). Jakarta: Pradanya Paramita, 1991.

Fajar ND., Mukti dan Yulianto Achmad, Dualisme Penelitian Hukum Normatif dan Empiris, Pustaka Pelajar, Yogyakarta, 2010.

Hadi Utomo, Warsito, Hukum Kepolisian Di Indonesia. Prestasi Pustaka. Jakarta, 2005.

Mahmud Marzuki, Peter, Penelitian Hukum, Prenada Media Grup, Jakarta, 2011.

Rahardjo, Satjipto, Polisi Sipil Dalam Perubahan Sosial Di Indonesia, Kompas, Jakarta, 2009.

Membangun Polisi sipil, Perspektif Hukum, Sosial, dan Kemasyarakatan, PT Kompas Media Nusantara, Jakarta, 2007.

Renggong, Ruslan, Hukum Acara Pidana (Memahami Perlindungan HAM dalam Proses Penahanan di Indonesia), Kencana, Jakarta. 2014.

Sitompul, Beberapa Tugas dan Peran Polri, CV. Wanthy Jaya, Jakarta, 2000.

Syamsudin, M., Operasionalisasi Penelitian Hukum, PT RajaGrafindo Persada, Jakarta, 2007.

Yahya Harahap, M., Beberapa Tinjauan mengenai Sistem Peradilan dan Penyelesaian Sengketa, Citra Aditya Bakti, Bandung, 1997.

\section{Peraturan Perundang-undangan}

Kitab Undang-Undang Hukum Pidana

Kitab Undang-Undang Hukum Acara Pidana

Undang-Undang Negara Republik Indonesia No. 2 Tahun 2002 tentang Kepolisian Negara Republik Indonesia

Surat Edaran Kapolri Nomor : SE/8/VII/2018 tanggal 27 Juli 2018.

\section{Makalah/Jurnal/Media Massa}

Barda Nawawi Arief, Kebijakan Legislatif dalam Penanggulangan Kejahatan dengan Pidana Penjara, Semarang: BP UNDIP cetakan ke-3, 2000.

Koerniatmanto Soetoprawiro, Dkk, Sistem Pertanggungjawaban Hukum Kepolisian Negara Republik Indonesia Secara Organisasional Maupun Personal, Naskah Publikasi, Lembaga Penelitian dan Pengabdian kepada Masyarakat, Universitas Katolik Prahayangan, Bandung, 2013

http:/ / handarsubhandi.blogspot.com/2014/11/tujuan-dan-manfaatmediasi.html Handar Subandi, Diakses pada 25 Desember 2019. 
Chrysnanda Dwilaksana, Corak Diskresi dalam Proses Penyidikan Kecelakaan Lalu Lintas, UI, Jakarta, 2001.

Markas Besar Kepolisian Negara Repulik Indonesia Sekolah Staf dan Pimpinan, Polmas Sebagai Implementasi Comunity Policing Bagaimana Menerapkannya?.

\section{Hasil Narasumber}

Bowo, Kepala unit 4 Reskrim Polres Sleman, Faktor diperlukannya mediasi penal dalam penyelesaian perkara pidana penggelapan, wawancara, 24 Desember 2018.

Hasil wawancara dengan Kompol Paridal pada 29 November 2019, di Polsek Depok Timur, Sleman, D.I.Y. 